\title{
STUDY ON THE AEROBIC MICROBE POPULATION DYNAMICS OF BULKING SLUDGE IN WASTEWATER TREATMENT
}

\author{
WANG, S. ${ }^{1,2}-$ XIAO, X. L. ${ }^{1 *}-$ CHENG, S. G. ${ }^{1,2}-$ LAI, F. ${ }^{1}-$ QIAO, X. R. ${ }^{3}$ \\ ${ }^{I}$ School of Environmental Science and Engineering, Shaanxi University of Science and \\ Technology, Xi'an 710021, China \\ ${ }^{2}$ National Demonstration Center for Experimental Light Chemistry Engineering Education, \\ Shaanxi University of Science \& Technology, Xi'an 710021, China \\ ${ }^{3}$ School of Arts and Sciences, Shaanxi University of Science and Technology, Xi'an 710021, \\ China \\ *Corresponding author \\ e-mail:xxl0108@163.com,phone:+86-136-3680-8617 \\ (Received 22 $2^{\text {nd }}$ May 2019; accepted $28^{\text {th }}$ Aug 2019)
}

\begin{abstract}
Activated sludge process is one of the most common methods in wastewater treatment, however, bulking sludge is nerve-wracking during the actual treatment. In this study, Polymerase chain reaction-denaturing gradient gel electrophoresis (PCR-DGGE) was employed to study the diversity of the micro-organisms of the untreated sludge and bulking sludge in the biological wastewater treatment. Simultaneously, microbe species and dominant microflora of the untreated sludge and the bulking sludge were analyzed. This paper provides a reliable theoretical basis to the prevention and control of the bulking of the activated sludge. The results indicate that the bulking of the activated sludge is mainly caused by the change of microbe population.
\end{abstract}

Keywords: PCR-DGGE, the diversity of microbe, bulking sludge, filamentous, dominant microflora

\section{Introduction}

The activated sludge treatment is an aerobic biological treatment. Under the aerobic condition, the organic matter in the wastewater is decomposed into inorganic materials, so as to purify the wastewater (Shao et al., 2005). Sludge bulking is a frequent and serious problem in plants using activated sludge, and the causes are fairly complex. Many researchers have studied this issue. The over-growth of many filamentous bacteria may cause the bulking problem (Henze et al., 2008). Simultaneously, theoretical studies on the overgrowth of the filamentous bacteria have also progressed (Eikelboom et al., 1975; Sezgin et al., 1980). The causes of sludge bulking can be divided into two types: the first is caused by the rapid multiplication of the filamentous bacteria in the activated sludge; and the other is caused by a large accumulation of highly viscous substances produced by bacterial colloid (Qin et al., 1989; Ma et al., 2012). In recent years, the metabolic diversity and genetic adaptability of microbes in sludge have been studied. Denaturing gradient gel electrophoresis (DGGE) fingerprint results indicated a shift in bacterial community composition during the granulation of aerobic granules, which was confirmed by 16SrRNA gene sequencing (Aqeel et al., 2015). Real-time quantitative polymerase chain reaction (qPCR) was used to study the abundance and community structure of ammonia-oxidizing bacteria in the activated sludge taken from different geographic 
regions in China (He et al., 2018). The abundance of filamentous morphotypes and floc-formers able to store biopolymers were analysed by PCR-DGGE and 16S amplicon sequencing (Meunier et al., 2016). With the development of modern molecular biotechnology such as DNA extraction, it is possible to analyze the diversity of microbial species and heredity (Li et al., 2015; Jiang et al., 2014).

In this study, PCR-DGGE was employed to study the micro-biodiversity of the untreated sludge and the bulking sludge. The species and dominant microflora of microbes in the two kinds of sludge were compared, and the causes of sludge bulking were found, which provides a reliable perspective for solving the problem.

\section{Materials and methods}

\section{Materials}

The experiment material was collected from the acclimated sludge and filamentous bulking sludge in a wastewater treatment plant Xi'an, China.

\section{Methods}

PCR-DGGE include preparation of sample DNA, PCR amplification and denaturing gradient gel electrophoresis (Sun et al., 2009).

\section{(1) Preparation of sample DNA}

Bacteria acquired through Centrifuge collection were dissolved in $5 \mathrm{~mL}$ extraction buffer $(100 \mathrm{mM}$ Tris $\cdot \mathrm{Cl}, 100 \mathrm{mM}$ EDTA-Na2, $200 \mathrm{mM} \mathrm{NaCl}, 2 \% \mathrm{CTAB}, \mathrm{pH}$ 8.0) and were shaken at $37{ }^{\circ} \mathrm{C}$ for $30 \mathrm{~min} .0 .75 \mathrm{~mL} \mathrm{20 \%} \mathrm{SDS} \mathrm{was} \mathrm{added} \mathrm{in} \mathrm{the} \mathrm{solution}$ above then water bathed it at $65^{\circ} \mathrm{C}$ for $1 \mathrm{~h}$. The supernatant was collected by centrifugation at $12000 \mathrm{rpm}$ for $10 \mathrm{~min}$. The volume (the same as the supernatant) of the mixture of phenol, Chloroform and Isoamyl alcohol, the ratio of which are 25:24:1, was extracted twice, $0.3 \mathrm{M}$ of $\mathrm{NaAC}(\mathrm{pH}$ 5.2) and ethyl alcohol which was twice as the volume as the extracted solution were added, and precipitated for $1 \mathrm{~h}$ at ambient temperature. After centrifugation (12000 rpm, $20 \mathrm{~min})$ at $4{ }^{\circ} \mathrm{C}$, the precipitate was collected and rinsed twice with 70\% ethanol, then dried and dissolved in $50 \mu \mathrm{l}$ TE.

\section{(2) PCR amplification}

PCR amplification primers used are F357(5' CGCCCGCCGCGCCCCGCGCCCGGCCCGCCGCCCCCGCCCCCCTACGGGAGG CAGCAG -3') and R518(5'- ATT ACC GCGGCTGCT GG -3') from bacteria 16SrDNA V3 Highly variable region for the analysis of the diversity of the bacteria in the activated sludge. PCR amplification primers used fungus NS1(GTAGTCATATGCTTGTCTC) and Fung-GC(GCATTCCCCGTTACCCGTTG) for the analysis of the fungal diversity.

\section{(3) Denaturing gradient gel electrophoresis (DGGE)}

D-Code Universal Mutation Detection System (Bio-Rad) was used for the DGGE of the PCR products. 


\section{Results and discussion}

\section{Analysis of the bacteria diversity of the untreated activated and bulking sludge}

After DGGE analysis and sequencing, the gene sequence was compared with the NCBI database, and the results of the main bacteria identification in the untreated sludge and bulking sludge were shown in Tables 1,2 and Figures 1,2.

Table 1. Identified bacteria species in the untreated sludge

\begin{tabular}{c|c|c|c}
\hline Stripe number & Clone number & V3 region & Bacteria species generic name \\
\hline 1 & $>8.15$ XDG123-1-M13- & $194 \mathrm{bp}$ & Zoogloea $\mathrm{sp}$. \\
2 & $>8.20$ XDG123-3-M13- & $194 \mathrm{bp}$ & Sterolibacterium $s p$. \\
3 & $>8.15$ XDG123-4-M13- & $194 \mathrm{bp}$ & Uncultured bacterium \\
4 & $>8.15$ XDG123-5-M13- & $194 \mathrm{bp}$ & Pseudomonas $s p$. \\
5 & $>8.15$ XDG123-8-M13- & $194 \mathrm{bp}$ & Legionella pneumophila \\
6 & $>8.15$ XDG123-9-M13- & $193 \mathrm{bp}$ & Uncultured bacterium \\
7 & $>8.15$ XDG123-10-M13- & $194 \mathrm{bp}$ & Uncultured Aquabacterium sp. \\
8 & $>8.15$ XDG123-12-M13- & $187 \mathrm{bp}$ & Uncultured bacterium \\
9 & $>8.15 X D G 123-15-M 13-$ & $174 \mathrm{bp}$ & Agrococcus lahaulensis \\
10 & $>8.15$ XDG123-18-M13- & $194 \mathrm{bp}$ & Uncultured Alcaligenes sp. \\
\hline
\end{tabular}

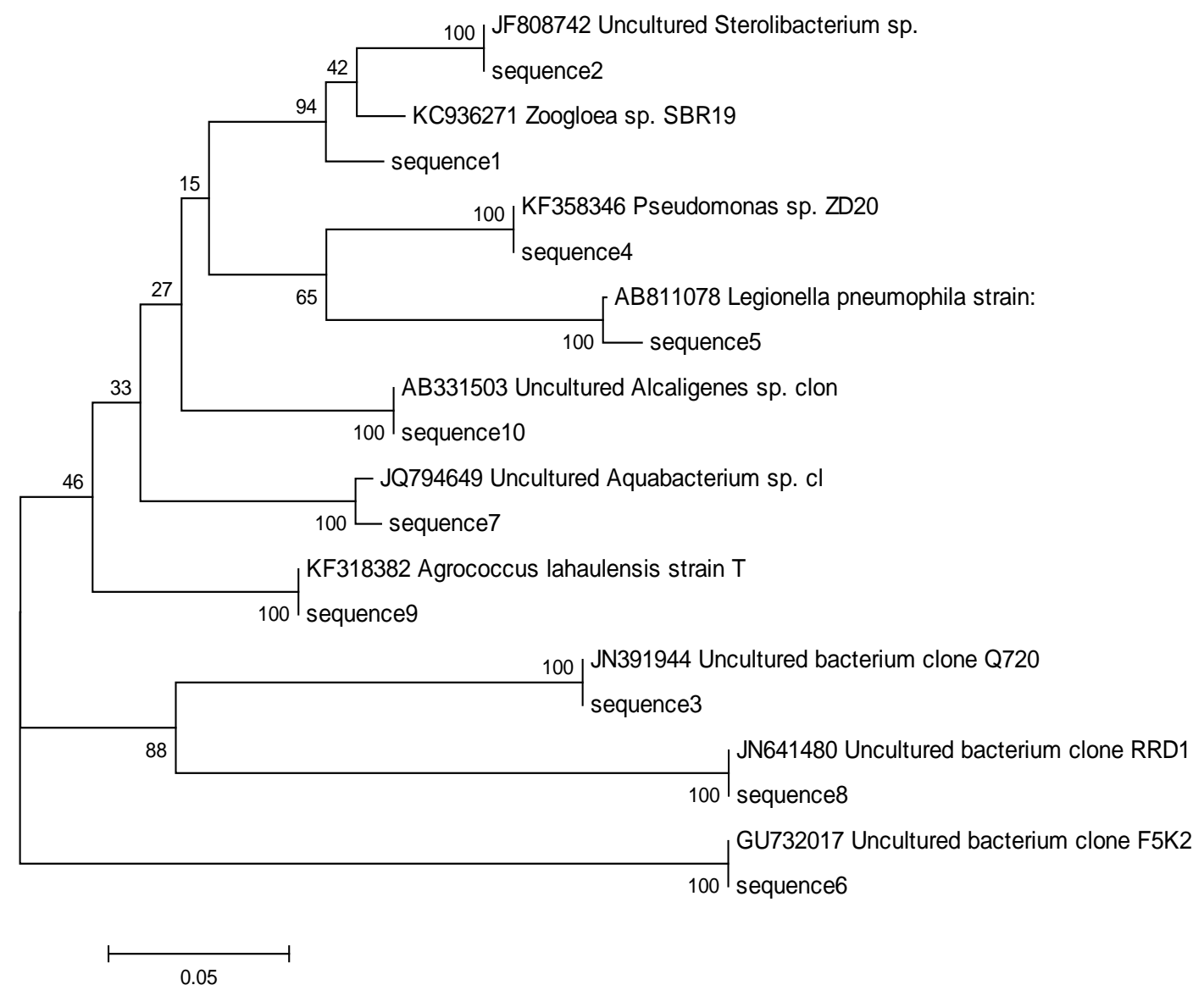

Figure 1. Phylogenetic tree of the bacteria in the untreated sludge 
Most bacteria in the untreated sludge belong to proteobacteria (including $\alpha$ proteobacteria,$\beta$-proteobacteria and $\gamma$-proteobacteria) (Table 1) and showed a close genetic relationship. Sequence 2, 1, 4, 5, 10, 7 stand for the dominant microfloras in the activated sludge. Moreover, the bacteria represented by sequence 3, 8, 6 were not artificially cultivated and classified, and they also showed a close genetic relationship. The microbe community of the activated sludge is formed together with the same 9 microbes (Wang et al., 2015).

Significant reduction in the total number of the dominant bacteria in the bulking sludge is showed from 10 species in the untreated sludge to 6 species (Table 2) after the treatment and the microbial community changed greatly.

The strains represented by sequence $2 \sim 5$ (Fig. 2) are in accordance with the four strains represented by sequence 5, 6, 8, 10 in the untreated sludge. Two strains of bacteria represented by sequence 1 and sequence 6 are new in the bulking sludge. Strains represented by sequence 1 and sequence 6 highly similar to the Anaerolineaceae and Collinsella aerofaciens, respectively.
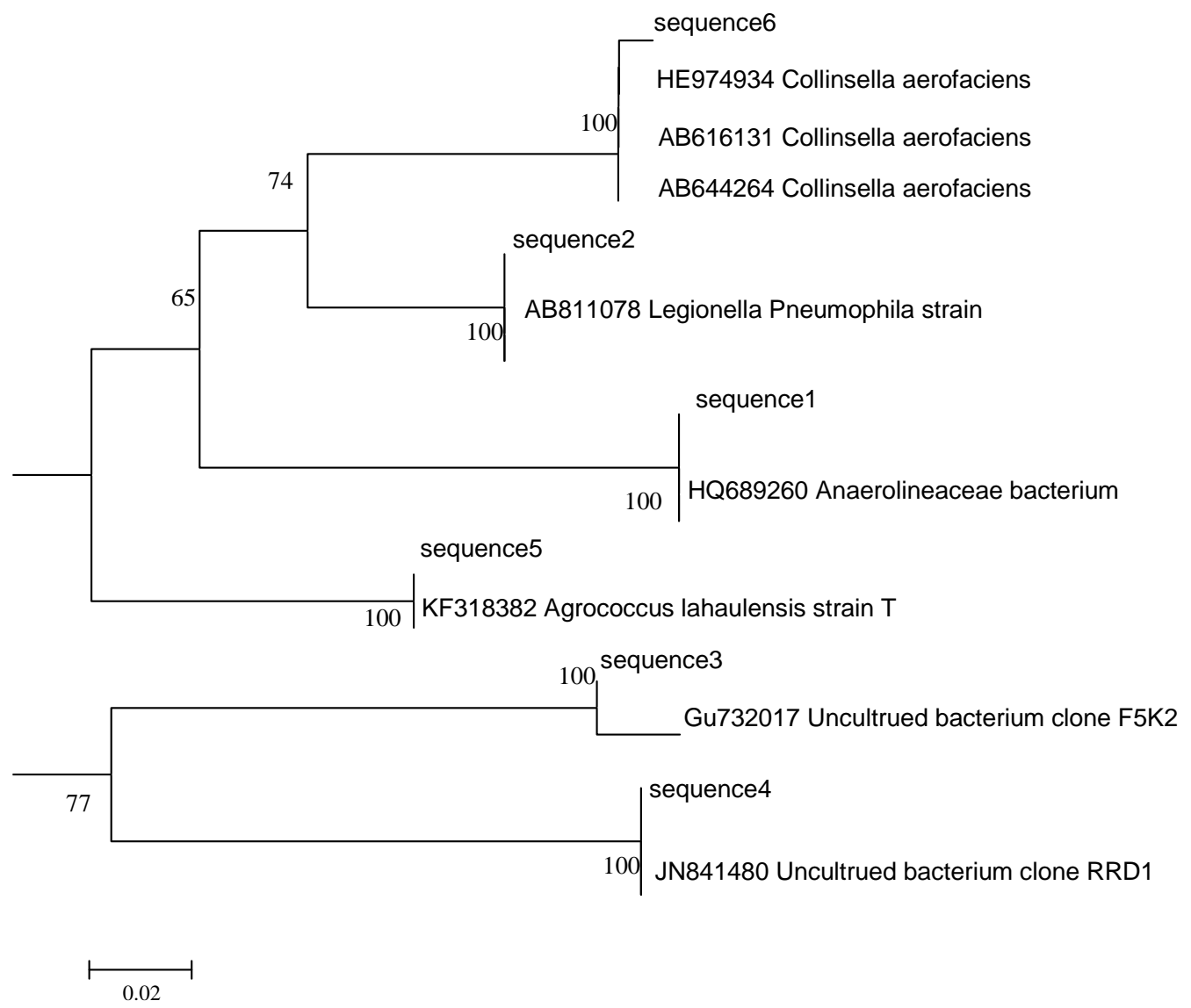

Figure 2. Phylogenetic tree of the bacteria in the bulking sludge

Table 2. Identified bacteria species in the bulking sludge

\begin{tabular}{c|c|c|c}
\hline Stripe number & Clone number & V3 region & Bacteria species \\
\hline 1 & $>7.11$ XD1512-2(DG50-X-4)M13- & $169 \mathrm{bp}$ & Anaerolineaceae \\
2 & $>7.11$ XD1513-1(DG50-X-5)M13- & $194 \mathrm{bp}$ & Legionella pneumophila \\
3 & $>7.18 X \mathrm{X} 1514-2(\mathrm{DG} 50-\mathrm{X}-6) \mathrm{M} 13-$ & $193 \mathrm{bp}$ & Uncultured bacterium \\
\hline
\end{tabular}




\begin{tabular}{l|c|c|c}
\hline 4 & $>7.11$ XD1515-1(DG50-X-7)M13- & $187 \mathrm{bp}$ & Uncultured bacterium \\
5 & $>7.11$ XD1517-2(DG50-X-9)M13- & $174 \mathrm{bp}$ & Agrococcus lahaulensis \\
6 & $>7.11$ XD1518-3(DG50-X-10)M13- & $170 \mathrm{bp}$ & Collinsella aerofaciens \\
\hline
\end{tabular}

\section{Analysis of fungus diversity of the bulking sludge}

After DGGE analysis and sequencing, the gene sequences were compared with the sequences in the NCBI database, and the main funguses in the bulking sludge were shown in Table 3.

Table 3. Identified funguses in the bulking sludge

\begin{tabular}{c|c|c|c}
\hline Stripe number & Clone number & V3 region & Fungus species \\
\hline 1 & $>7.24$ XD1534-6(DG50-Z-2)M13- & $349 \mathrm{bp}$ & Uncultured eukaryote \\
2 & $>7.24$ XD1535-1(DG50-Z-3)M13- & $349 \mathrm{bp}$ & Saccharomyces cerevisiae \\
3 & $>8.16$ XD1631-2(DG50-Z-4)M13- & $347 \mathrm{bp}$ & Unculture alveolate \\
4 & $>8.16$ XD1632-1(DG50-Z-5)M13- & $346 \mathrm{bp}$ & Hanseniaspora guilliermondii \\
5 & $>8.16 \mathrm{XD} 1633-1$ (DG50-Z-8)M13- & $337 \mathrm{bp}$ & Uncultured eukaryote \\
\hline
\end{tabular}

The bulking sludge contains five kinds of funguses (Table 3), besides bacteria, they constitute the microbial community of the sludge, and are a part of the dominant microflora in the bulking sludge. The genus can be identified by cloning V3 conservative regions. The result is shown in Figure 3.

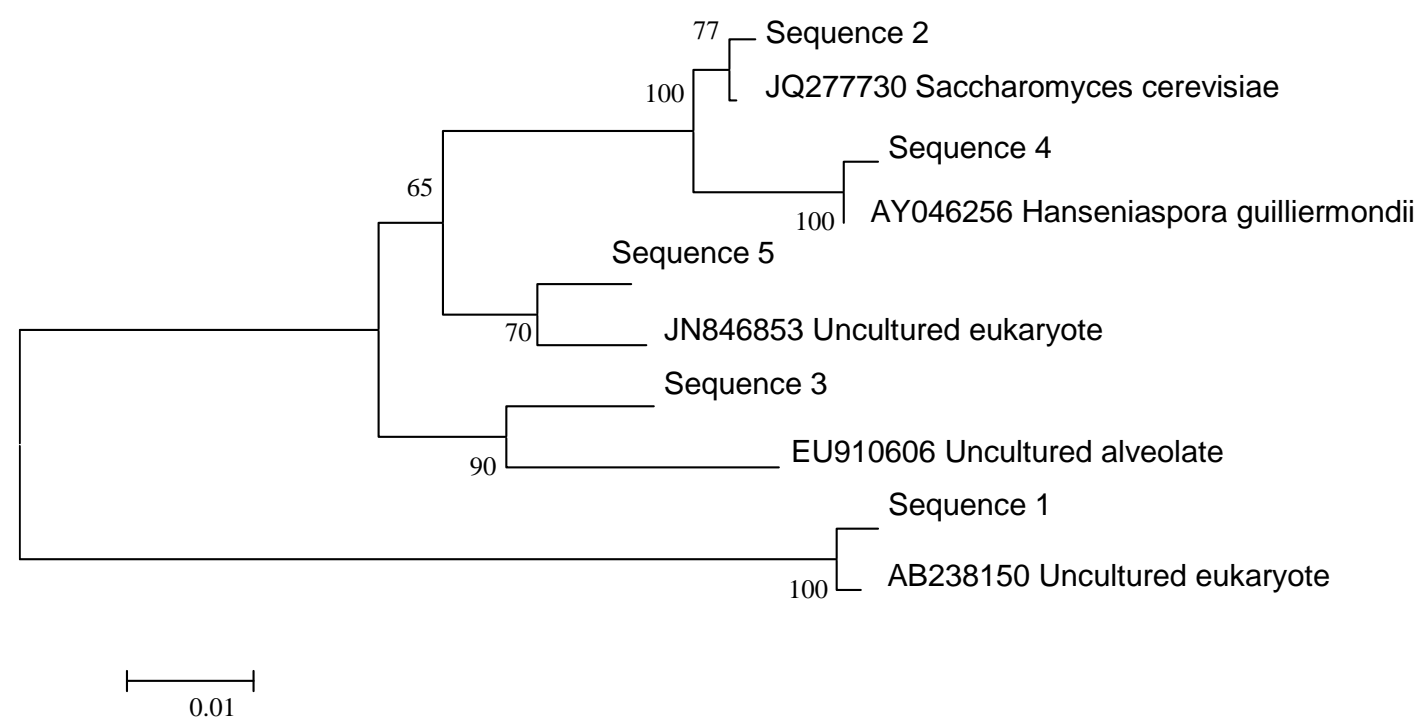

Figure 3. Phylogenetic tree of the funguses of in the bulking sludge

From Figure 3, the funguses represented by sequence 1, 3 and 5 are not artificially cultivated strains. The two fungus strains represented by sequence 2 and sequence 4 were closely related to Saccharomyces cerevisiae and Hanseniaspora guilliermondii in the evolutionary relations. So the two funguses were identified as Saccharomyces cerevisiae and Hanseniaspora guilliermondii. 


\section{Analysis of the root causes of sludge bulking}

\section{(1) Changes of bacterial composition of non-treated and bulking sludge}

From the results of DGGE analysis in Figure 4, it can be seen that bacterial composition changed greatly after sludge bulking, showing a decrease of bacterial species and the change of the amount of the dominant microflora. The microflora represented by sequence 1 in the untreated sludge are Zoogloea sp. Under natural conditions, the Zoogloea $\mathrm{sp}$. produces capsule that not only directly affects the growth and reproduction of the bacteria but also the living environment of the bacteria. Bacteria can improve the poor living environment with its capsule property, and prevent the phagocytosis and utilization by some bad cell tissue. And on the surface of some specific bacteria cells, it showed a strong specificified of attack and defense capability (Wang, 2016). Microfloras which are commonly used microbes in sewage treatment cluster in the common bacteria colloid, so that the sludge has a good gel-flocculation structure and sedimentation property (Zhong et al., 2010). The disappearance of Zoogloea sp. in the sludge is the direct cause of sludge bulking.

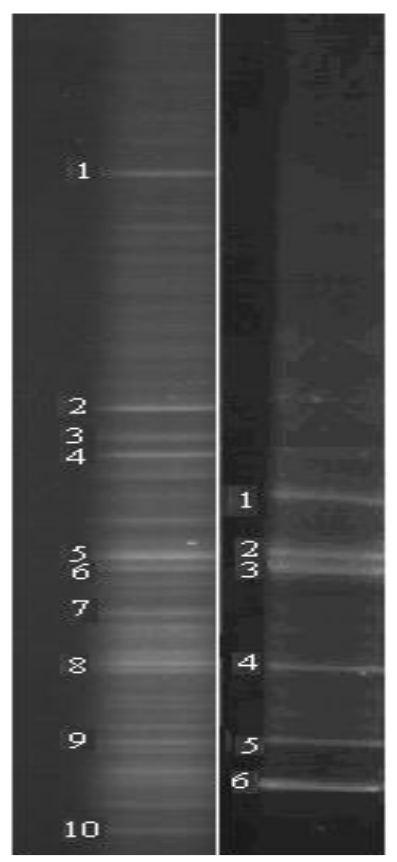

Figure 4. Bacteria domains in the untreated sludge and bulking sludge

\section{(2) Changes of funguses composition of the untreated and bulking sludge}

As can be seen from the DGGE bands in Figure 5, the fungus bands in the untreated sludge are few and unclear, indicating that the types and amounts of the funguses contained in the untreated sludge are small but the bulking sludge contains five kinds of fungi whose species and quantity are much more than the untreated sludge. Thus, the multiplication of fungi has changed the nutritional composition of the environment, absorbing a large number of nutrients, directly affect the growth of the bacteria such as Zoogloea sp. Thereby, the change of the composition of the microbe microfloras in the sludge, as well as the destruction of the flocs structure of the sludge lead to the sludge bulking. 


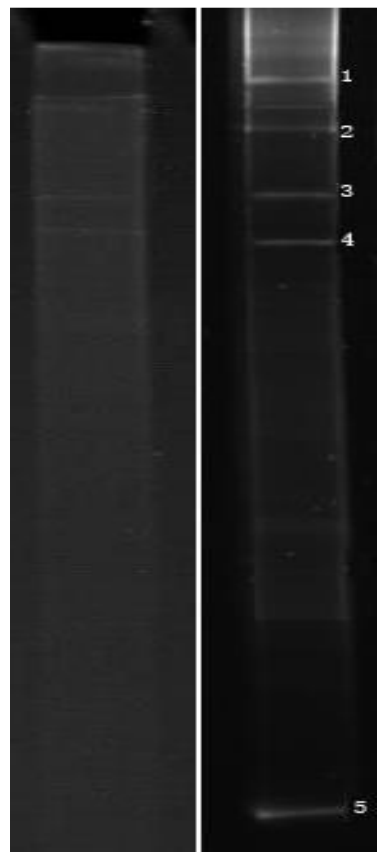

Figure 5. Fungus domains in the untreated sludge and bulking sludge

\section{Conclusion}

From the analysis of the diverse microbes of untreated sludge and bulking sludge, it is seen that sludge bulking is mainly caused by the change of microbe microfloras.

(1) The sludge bulks because the microfloras in it changed greatly, the main signs are the decrease of the bacterial species and the dominant flora changes. Under natural conditions, Zoogloea $\mathrm{sp}$. in the untreated sludge flora has the property of producing capsule and the bacteria which are the common microbes in wastewater treatment cluster in the common bacteria colloid, so that the sludge has a good gel-flocculation structure and sedimentation property. The disappearance of Zoogloea sp. is one of the direct causes of sludge bulking.

(2) DGGE analysis of the untreated sludge showed that only a very small amount of fungi were present in the activated sludge, which indicates that the activated sludge mainly consisted of bacteria, but five kinds of filamentous fungi (most of which have hyphae) in the bulking sludge were detected with the same method. The mass growth of these filamentous fungi has replaced the predominant bacteria such as Zoogloea $s p$. in the activated sludge, therefore, the destruction of the gel-flocculation structure of the sludge eventually leads to the filamentous fungus sludge bulking.

In the future studies, the changes of carbon source, nitrogen source and inorganic salts in sludge before and after bulking should be systematically analyzed. Combined with the study of microfloras changes and strain metabolism, the mechanism of change would be deeply revealed, which would lay a theoretical foundation for controlling the sludge bulking.

Acknowledgements. The authors are grateful for the financial support from Technical Innovation Guidance Project of Shaanxi Province(2019CGXNG-039), Shaanxi Science and Technology Plan Project (2018SF-377), Open Project Program of National Experimental Demonstration Center for Experimental Light Chemical Engineering (2018QGSJ02-04, (Shaanxi University of Science and Technology), Science and Technology project of Xi' an (2017068CG/RC031 (SXKD002). 


\section{REFERENCES}

[1] Aqeel, H., Basuvaraj, M., Hall, M. (2015): Microbial dynamics and properties of aerobic granules developed in a laboratory-scale sequencing batch reactor with an intermediate filamentous bulking stage. - Environmental Biotechnology 100(1): 447-460.

[2] Eikelboom, D. H. (1975): Filamentous organism observed in activated sludge. - Wat. Res 6: $148-154$.

[3] He, R. J., Zhao, D. Y., Xu, H. M. (2018): Abundance and community structure of ammonia-oxidizing bacteria in activated sludge from different geographic regions in China. - Water Science \& Technology 77(6): 1698-1705.

[4] Henze, M., van Loosdrecht, M. C. M., Ekama, G. A., Brdjanovic, D. (2008): Biological Wastewater Treatment: Principles, Modelling and Design. - IWA Publishing, London.

[5] Jiang, Y. X. (2014): Analysis of community structure of sludge microbes based on molecular biology technology. - Master's thesis, Beijing University of Chemical Technology.

[6] Li, S., Zhang, L., Qiu, Y. L. (2015): Study on microbial diversity of sludge in rural biogas digester. - Life Science Research 4: 321-327.

[7] Ma, J. M., Li, D., Wu, D. (2012): Study on filamentous sludge bulking in A/O phosphorus removal process. - China Water and Wastewater 28(7): 38-42.

[8] Meunier, C., Henriet, O., Schoonbroodt, B. (2016): Influence of feeding pattern and hydraulic selection pressure to control filamentous bulking in biological treatment of dairy wastewaters. - Bioresource Technology 221: 300-309.

[9] Qin, L. Y. (1989): Biological Treatment of Wastewater. - Tongji University Press, Tongji, pp. 197-199.

[10] Sezgin, M., Jenkins, D., Palm, J. C. (1980): Floc size, Filament length and settling properties of prototype activated sludge plants. - Wat. Res. 11(12): 68-73.

[11] Shao, Q. X. (2005): Characteristics and effects of main microbial groups in activated sludge. - Shanxi Architecture 4: 30.

[12] Sun, J. (2009): Application of denaturing gradient gel electrophoresis in the identification of microalgae and the study of phytoplankton community structure. - $\mathrm{PhD}$ thesis, Ocean University of China.

[13] Wang, T., Liu, L. L., Zhang, K. Q. (2015): Effect of fertilizer irrigation on soil ammonia oxidizing microorganisms. - Journal of Agriculture Environment Science 34(9): 17371746.

[14] Wang, Z. (2016): Changes of the core polysaccharide structure of E. coli lipopolysaccharide molecule effect on cell membrane and intracellular metabolism. $\mathrm{PhD}$ thesis, University of Jiangnan, China.

[15] Zhong, S. G. (2010): Singular integral equations on the real axis with solutions having singularities of higher order. - Acta Mathematica Scientia 25: 1093-1099. 